\title{
Construction of the matrix of individual nursing competences in surgical units
}

\author{
Construção de matriz de competências individuais do enfermeiro em unidades cirúrgicas \\ Construcción de la matriz de competencias individuales del enfermero en unidades quirúrgicas
}

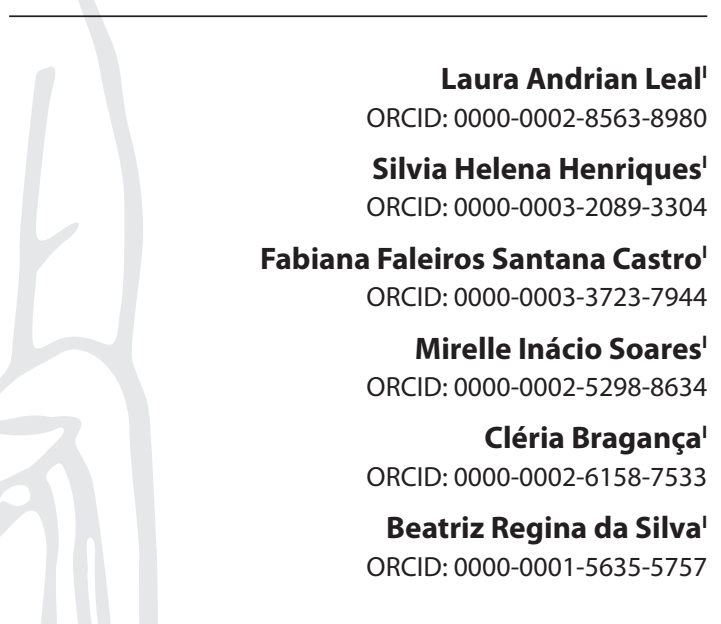

'Universidade de São Paulo. Ribeirão Preto, São Paulo, Brazil.

How to cite this article:

Leal LA, Henriques SH, Castro FFS, Soares MI, Bragança C Silva BR. Construction of the matrix of individual nursing competences in surgical units. Rev Bras Enferm. 2020;73(6):e20190584. doi: http://dx.doi.org/10.1590/0034-7167-2019-0584

\section{Corresponding author:} Laura Andrian Leal

E-mail: laura.andrian.leal@usp.br

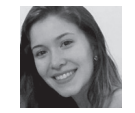

EDITOR IN CHIEF: Antonio José de Almeida Filho ASSOCIATE EDITOR: Hugo Fernandes

Submission: 10-03-2019

Approval: 03-26-2020

\section{ABSTRACT}

Objective: to build and to describe an Individual Skills Matrix for nurses working in surgical units and their associated behaviors / attitudes. Method: Exploratory, qualitative study. 43 nurses from five surgical units participated, and data collection was carried out between April and September 2017. The focus group technique was used and for data interpretation an inductive thematic analysis was performed. The competence matrix was built from the testimonies of the participants plus a search in the literature for concepts directed to each competence and description of the expected behaviors and / or attitudes. Results: For the Matrix, the following individual skills were identified: Planning; Communication, Relational Competence, Leadership, Decision Making and Ethics. Final Considerations: The construction of a Matrix should assist managers in recognizing the professional profile and assessing their performance, strengthening the achievement of professional and organizational objectives, as well as contributing to the quality and effectiveness of the care provided by nurses in these places.

Descriptors: Nurses; Perioperative Nursing; Professional Competence; Surgical Centers; Hospitals.

\section{RESUMO}

Objetivo: Construir e descrever uma matriz de competências individuais e comportamentos/ atitudes associados para enfermeiros atuantes em unidades cirúrgicas. Métodos: Estudo exploratório, qualitativo. Participaram 43 enfermeiros de cinco unidades cirúrgicas, sendo a coleta de dados realizada entre abril a setembro de 2017. Utilizou-se a técnica de grupo focal e, para interpretação dos dados, realizou-se análise temática indutiva. A matriz de competência foi construída a partir dos depoimentos dos participantes acrescida de busca na literatura de conceitos direcionados para cada competência e descrição dos comportamentos e/ou atitudes esperadas. Resultados: Para a matriz, foram identificadas as seguintes competências individuais: Planejamento; Comunicação; Competência relacional; Liderança; Tomada de decisão; e Ética. Considerações Finais: A construção de uma matriz deve auxiliar gestores no reconhecimento do perfil profissional e na avaliação do desempenho, a fim de fortalecer o alcance dos objetivos profissionais e organizacionais, bem como contribuir para qualidade e efetividade do cuidado prestado pelo enfermeiro nesses locais.

Descritores: Enfermeiros; Enfermagem Perioperatória; Competência Profissional; Centros Cirúrgicos; Hospitais.

\section{RESUMEN}

Objetivo: Construir y describir una matriz de competencias individuales y comportamientos/ actitudes relacionadas para enfermeros actuantes en unidades quirúrgicas. Métodos: Estudio exploratorio, cualitativo. Participaron 43 enfermeros de cinco unidades quirúrgicas, siendo la recogida de datos realizada entre abril a septiembre de 2017. Ha sido utilizada la técnica de grupo focal y, para interpretación de los datos, se ha realizado análisis temático inductivo. La matriz de competencia ha sido construida a partir de las deposiciones de los participantes acrecida de búsqueda en la literatura de conceptos enfocados para cada competencia y descripción de los comportamientos y/o actitudes esperadas. Resultados: Para la matriz, han sido identificadas las siguientes competencias individuales: Planeamiento; Comunicación; Competencia relacional; Liderazgo; Toma de decisión; y Ética. Conclusión: La construcción de una matriz debe auxiliar gestores en el reconocimiento del perfil profesional y en la evaluación del desempeño, a fin de fortalecer el alcance de los objetivos profesionales y organizacionales, así como contribuir para calidad y efectividad del cuidado prestado por el enfermero en estos locales.

Descriptores: Enfermeros; Enfermería Perioperatoria; Competencia Profesional; Centros Quirúrgicos; Hospitales. 


\section{INTRODUCTION}

The Surgical Center Unit (SCU), composed of the surgical ward, surgical center and post-anaesthetic recovery room, constitutes a complex sector due to the technology available, the intrinsic variation in its work processes and the situation of vulnerability of patients. The nursing team is coordinated by nurses who, depending on the way they organize their work, can interfere in the quality of care provided, thus affecting the hospital institution in a relevant way ${ }^{(1-2)}$.

The nurse working in surgical units is responsible for numerous activities, whether assistance and/or managerial. Therefore, rethinking the necessary skills that can guide your professional practice is a relevant aspect to reflect on gaps in knowledge, skills and attitudes of this professional. In this perspective, the competences are directed to individuals with knowledge and possessing skills and attitudes to develop their work effectively; and managers must use tools that promote the filling of these $\operatorname{gaps}^{(2-3)}$.

In this sense, there are researchers who divide competences into three dimensions: essential, functional and individual competences ${ }^{(4)}$. Essential competencies are those that are related and that express the organizational dimension of the competencies, being the reason for survival of the companies ${ }^{(5-6)}$. Functional competences, also called collective competencies, are the essential competencies for the specific functions of each area of a company, and must be present in the employees of each sector ${ }^{(7)}$. Finally, individual skills consider attitudes and behaviors combined with the duties to be exercised by professionals ${ }^{(6)}$.

For the area of surgery, nine skills have already been identified for nurses working in post-operative cardiac surgery units, namely: theoretical-practical knowledge, highly complex nursing care, supervision and leadership, decision making, conflict management, human resources, material, financial and continuing education in service ${ }^{(8)}$. However, the incipient literature that involves the training and provision of a matrix of individual skills for SCU nurses stands out.

In Brazil, the reality of SCUs is quite different when compared to other countries, such as, for example, Americans, where nurses perform all professional activities without class division, since in our country there are other categories, for example: nursing technician, anaesthesia assistant, surgical instrumentation technician and nursing technician who works in anaesthetic recovery rooms $\mathrm{s}^{(9)}$. In this case, nurses are responsible for the care and management of the sector, which leads us to reflect on the relevance of building a matrix that includes the individual skills needed by nurses working in surgical units, according to their perceptions of reality.

In view of this premise, a competency matrix is a tool that provides better use of human resources for the function that will be exercised in the organization, through the development of skills in professionals, in order to guarantee the quality of the services provided. In this sense, a competency matrix can be defined as a set of minimum competencies necessary for professionals to carry out their activities efficiently ${ }^{(10)}$.

Due to this, the construction of a competency matrix for nurses in surgical units may serve as a reference or strategy for managers of health institutions in which this professional is present, in order to guide the way of recruiting people, in this case, recruiting and selecting professionals with the skills necessary for the position to be filled, contributing to the organization's success, especially in this sector. This matrix should also contribute to awaken man management to apply to people, by evaluating the performance of professionals based on the skills they have and that they should present, promoting the modelling of these individuals for work.

Therefore, the following questions are presented: What are the individual skills needed by nurses in surgical units? Is it possible to define a skills matrix for these professionals? What behaviors and attitudes are associated with competencies?

It is believed that the identification of skills by the perception of the worker, allows to build a matrix of individual skills needed by the perioperative nurse defining behaviors and/or attitudes associated with them, enabling the institution to recognize the profile of their human talent. In addition, it will be able to direct the Training Centers in the preparation of future professionals, thus contributing to the improvement of perioperative nursing care.

\section{OBJECTIVE}

To build and to describe an Individual Skills Matrix for nurses working in surgical units and their associated behaviors/attitudes.

\section{METHOD}

\section{Ethical aspects}

This study was carried out in accordance with resolution 466/2012 and approved by the Research Ethics Committee (REC), the participants signed the Free and Informed Consent Form, confidentiality of responses is ensured. Therefore, in order to preserve the anonymity of the participants in this research, we chose to use the letter " $E$ " for a nurse, followed by the Arabic numeral, according to the increasing chronological order of the groups and each participant.

\section{Type of Study and Methodological Procedures}

Exploratory study, using the qualitative approach. The study was developed according to the COREQ precepts (for qualitative research).

\section{Scenario, Study Participants and Data Sources}

Held in five private hospital institutions in a city in the "Triângulo Mineiro" region. The data collection period took place between April and September 2017. As inclusion criteria, nurses belonging to the SCU service were selected, of both sexes with more than six months of employment and as exclusion criteria, nurses on vacation or on sick leave and maternity leave. Because of this, the final sample consisted of 43 nurses from SCU.

\section{Data Collection, Organization and Work Stages}

For data collection, the Focus Group (FG) technique was used ${ }^{(11)}$. 
The groups were carried out after definition with the institution's technical managers about the most appropriate date, time and place. Each group lasted an average of 50 to 55 minutes. The number of participants in each FG was organized and distributed as follows: eight nurses participated in hospital I; in hospital II, two FGs were carried out with the participation of six nurses in each group, being appointed as focus group I and II; two groups were held due to the number of nurses at the institution's SCU. In hospital III, seven nurses participated, in hospital IV, nine nurses and finally in hospital V, seven nurses participated. It should be emphasized that workers who belonged to more than one private institution, participated only once in the FG, according to their choice and availability.

In addition, the FG(s) were guided by a script that considered the objectives of the research, and the questions were about the skills necessary for the nurse to perform in SCU, such as: What are the skills perceived by you as necessary for your performance in a Surgical Center Unit? Can competencies be individual and/or collective? Do you notice if your institution has used strategies to develop skills in nurses? What are these strategies? As well as this, the groups were conducted by the researcher (moderator) and a research assistant (observer) in order to describe all the situations identified by the nurses. In this sense, digital recorders were used during the sessions, in order to fully record the speeches of the participants.

\section{Data Analysis}

The data was analyzed through thematic inductive analysis and organized into thematic categories following three stages: pre-analysis, exploration of the material and treatment of the results obtained. Inductive thematic analysis is a method that contributes to the identification and analysis of themes extracted from the data; enables organization and describes in detail the set of information, serving as a useful and flexible research tool that allows a detailed, rich and complex report ${ }^{(12)}$.

Due to this, we sought to identify the individual skills essential for the perioperative nurse's work process, and it was also possible to show behaviors and attitudes related to each of the skills highlighted by the participants' perception. Subsequently to this stage, we gathered all the material, plus concepts from the scientific literature directed to each competence and thus ended the matrix of individual competencies for the SCU nurse.

\section{RESULTS}

\section{Characterization of participants}

43 nurses working in SCU. There was a predominance of females $(n=39 ; 90.6 \%)$, in which the age range of the participants varied between 20 and 29 years ( $n=17.2 ; 48.80 \%$ ). The highest number of years of experience was from one to two years ( $\mathrm{n}=$ 8.4; 20.90\%), since 24 (58\%) participants stated that they had professional experience in other hospitals with an average of three years working in SCU. In addition, 30 (72\%) said they had been prepared in undergraduate courses to work at SCU, however, only seven (16\%) said they were specialists to work specifically in the referred unit and another 10 (23.25\%) said they had specializations in other areas.

\section{Matrix of individual competencies for the nurse's perfor- mance in the Surgical Center Unit}

After conducting the focus groups, analyzing the testimonies of the participants, as well as the literature cited, it was possible to map the skills needed by the perioperative nurse and thus carry out the construction of an Individual Skills Matrix for this professional. For this study, it is relevant to highlight that individual skills are considered, those highlighted in the theoretical framework, that is, related to the individual's attitudes and behaviors ${ }^{(5-7)}$. Thus, six individual skills of the perioperative nurse were identified: Planning the unit and nursing care; Nursing communication; Relational competence; Nursing leadership; Nursing managerial decision making and Ethics.

Chart 1 reveals the matrix in its composition with concepts of individual competencies and their respective behaviors/attitudes that should be used by nurses from SCUs.

Chart 1 - Matrix of individual competencies with their nurses' behaviors/ attitudes in Surgical Units, Ribeirão Preto, São Paulo, Brazil, 2017

\section{INDIVIDUAL COMPETENCES}

Planning of the unit and nursing care

It is the ability to organize, schedule activities and actions related to nursing care according to current situations.

\section{Behaviors/attitudes}

- Characterize the available assets and those that need to be recruited;

- Identify the profile of nursing professionals that are recruited in this context.

- Plan and elaborate the manual of regulations and routines of the sector, protocols, as well as the standard operational procedures (sops).

- Identify the sector's problems in relation to the people and work routines of the nursing team, making the diagnosis of reality and, thus, planning priorities, seeking solutions, in the short and long term.

- Organize the service, the activities to be carried out in the surgical unit and indicate them to the nursing team.

- Schedule the activities performed inside the operating room and specificities of the sector, such as the physical structure, the work routine.

- Organize the process for the assembly and disassembly of the operating room, as well as the material needed to perform the surgical procedure.

- Know the computerized data recording system for scheduling surgeries and user records, as well as surgical indicators.

- Identify surgical scale procedures and elaborate/organize an agenda aimed at the fulfilment of scheduled surgeries.

- Carry out the comprehensive care plan for the user during their stay in the surgical unit, ensuring their reception.

- Apply the steps of the nursing process in order to systematize care in the surgical unit in order to plan its actions and prevent complications.

\section{Nursing communication}

It is the ability to share information, ideas, suggestions that contribute to the smooth running of the service.

\section{Behaviors/attitudes}

- Express yourself with clarity, precision and make yourself understood, verbally, in the form of records, for your team members and other professionals of the Surgical Unit and support sectors.

- Try to adapt your speech and language with different professional categories.

- Be assertive in exposing your ideals and being able to arouse the attention of the nursing team. 
Chart 1

\section{Relational competence}

It is knowing how to deal with situations that generate disagreement between the teams; this implies dialogue, deep knowledge of the work dynamics to find possibilities/alternatives in order to solve the existing problems, whether related to human, material or financial resources.

\section{Behaviors/attitudes}

- Develop collaborative and cooperative relationships within the unit.

- Assist the team in conflict management, approaching workers in a respectful, cordial manner, showing understanding in adverse situations.

- Demonstrate respect for the opinions of the multidisciplinary team, listening to and valuing them.

- Listen carefully and be accessible to the unit's health and nursing staff, facilitating the creation of bonds.

- Demonstrate self-confidence in the relationship with the team, act in different contexts preserving harmonious interaction with superiors and subordinates.

- Meet with the multi-professional team, establishing a constant dialogue about the activities and incidents of the surgical unit, promoting the sharing of ideas, negotiation and conflict management.

- Support the team when there are situations that generate interpersonal and work conflicts.

\section{Nursing leadership}

It is the ability to command, direct, influence and motivate people and groups in a positive way in order to achieve a common goal, stimulating initiative and accountability.

\section{Behaviors/attitudes}

- Promote a group sense of participation and mutual collaboration.

- Encourage initiative, proactivity, as well as autonomy, delegating tasks to be performed and sharing responsibilities with the team.

- Encourage compliance with surgery schedules according to what was planned without allowing unnecessary changes in the surgery map to meet the particular purpose of the anaesthetic or medical team.

- Guide and supervise and evaluate the use of equipment.

- Guide and supervise the nursing team.

- Encourage team improvement through permanent education.

- Present monthly report on surgical quality indicators, proposing improvement strategies with the team.

- Propose daily and monthly schedules distributing their professionals according to their knowledge, skills and attitudes.

- Apply a tool to assess the professional performance of the nursing team.

\section{Nurses' managerial decision-making}

It is the nurse's ability to characterize situations in the context of work, listing possible solutions, and take the necessary measures in a timely manner, effectively, that is, to act in situations that require decision making for their resolution.

\section{Behaviors/attitudes}

- Take measures or make choices to direct actions to solve problems, or situations in the work environment, in a timely manner, bearing in mind the priorities of the service and the urgency of the situations.

- Analyze the alternatives for solving problems in the sector and their potential implications for the service, fundamentally choosing the appropriate options.

- Be self-confident and determined to make decisions, even when it comes to difficult choices.

- Assume co-responsibility for decisions made in front of the nursing team in the Surgical Unit.

\section{Ethics}

It is the ability that each professional has to think before acting, and make the right decisions, taking into account the ethical values of the profession; to act with fairness, always taking into account impartiality in decision making, as well as having knowledge and respecting the professional code of ethics.

\section{Behavior/attitudes}

- Know the legislation and demonstrate commitment to your professional responsibilities.

- Act on confidential information that you have access to, in a strict, confidential manner, respecting legal, ethical and deontological principles.
Chart 1 (concluded)

- Know and always apply the professional code of ethics in matters related to the team, acting with impartiality, fairness and professional ethics in judging issues.

- Notify the ethics committees and nursing councils of situations that do not comply with the legislation and that disrespect the code of ethics, be they institutional or the team's.

- Know and apply the code of ethics in customer service whenever necessary, respecting their autonomy and singularities of each user.

- Recognize and guide your team on issues of posture and morals and ethics at work.

\section{DISCUSSION}

The researchers of the present study proposed to build a skills matrix for nurses working in SCU, based on the experiences and perceptions of these professionals. It is known that in hospital institutions, the description of competencies for a given position or function is not always a concern or priority for managers, who, due to the excessive amount of administrative activities, do not identify or describe the professional profile of nurses required for each area of activity. This fact even complicates the processes of recruiting and selecting workers, reflecting in inadequate hiring with consequences for the care provided to service users ${ }^{(13-14)}$.

Thus, it is emphasized that in this investigation there was a predominance of young female nurses, only with the preparation of academic training to work in SCU, most of them without specialization in the area. However, this preparation of academic training seems to be insufficient, corroborating the search for the complementation of knowledge through specializations that can enable the improvement of their knowledge and updating of their practices, as well as professional valorization ${ }^{(13)}$.

In addition, the data revealed a reduced time of professional experience of the participants, which suggests that these workers will have some difficulty in effectively responding to all demands that arise in their daily work. This premise can also generate professional insecurity for work, stimulating the employee to seek learning in courses or specializations for their improvement, or even causing demotivation for work ${ }^{(15)}$.

In this sense, the identification of competencies for SCU nurses created the possibility of building a Matrix that has in its content the definition of each individual competence with their attitudes and/or behaviors expected to reach them. The availability of this matrix should assist professionals, as well as health managers. Hence, the following individual skills were identified: Planning of the unit and nursing care; Nursing communication, Relational competence, Nursing leadership; Nursing managerial decision making; Ethics.

Thus, nursing care planning can be defined in the matrix as the ability to organize, schedule activities and actions related to nursing care through current situations, considered an essential individual competence for perioperative nursing. It is known that users who undergo surgery require planned, organized and systematized nursing care, in such a way as to guarantee qualified and humanized care. This way, the role of nurses in care planning is of paramount importance and should be directed towards a quick recovery of the user due to the surgical anaesthetic procedure ${ }^{(16)}$.

When planning care, the perioperative nurse must mobilize behaviors/attitudes with respects to the organization of assistance and administrative activities in the sector, such as preparing a manual 
of regulations and routines, carrying out a comprehensive care plan for the user, in order to lead the team and, subsequently, be able to evaluate the care provided according to their needs. However, it is necessary to reflect so that the planning competency is effective, the association of another competence is essential: communication.

Communication competence was pointed out as the ability to share information, ideas and suggestions that contribute to the smooth running of the service. Considering the large contingent that nursing represents in hospital sectors, the nurse is recognized as the professional who must provide communication between the various workers, as well as the users, hence meeting the needs of those who require a shared solution, contributing to the comprehensive health care ${ }^{(17)}$.

Furthermore, it is observed that the perioperative nurse when using an assertive communication, expresses oneself with clarity, precision, adapting his speech of language in the different professional categories and being assertive in the presentation of ones ideas, managing to arouse the attention of the nursing team, promoting a favorable organizational climate ${ }^{(18)}$.

The nurse who assumes the role of manager, regardless of the area of activity, should be the mediator of conflicting situations, carrying out negotiations between the different teams in order to solve the problems, since conflict situations are common, especially in institutions health care where professionals with diverse knowledge work; the lack of solutions to conflicts can have disastrous consequences for the team and risks for the user ${ }^{(19)}$.

In this sense, according to the exposed in the matrix of individual competencies, the nurse manager of surgical units needs to have relational competence to deal with situations that generate disagreement between the teams; this implies knowing how to dialogue, deeply knowing the work dynamics to find loopholes or alternatives to solve existing problems, whether related to human, material or financial resources, as well as always being in direct contact with the hospital administration to expose the needs of the sector.

When establishing guidelines and protocols in health units, respecting ethical principles in the workplace, the tendency is for conflicts to be mitigated over time. Thus, the nurse who works in SCU must establish with the hospital organization and with the other team members, the conduct and guidelines utilized in their work process, which can reduce conflicting situations, as well as being proactive in identifying problems and anticipating before they occur, in addition to making it clear to other professionals that there are rules that were thought out, built for the work routine and that should serve as a guide to avoiding future problems.

In this context of interpersonal relationships, a nurse leader becomes an important element within the SCU team. Leadership, a competence identified in the Matrix, involves several characteristics, amongst them, commitment, responsibility, empathy, ability to make decisions, communication and management in an appropriate and effective way. Leadership skills require professionals not only to learn management techniques, people and material management, but also a set of personal, behavioral and relationship characteristics, which are acquired from their experiences $^{(20-21)}$.

Due to this, in surgical units that have highly complex activities, leadership implies mastering their actions, being present when necessary, knowing all stages of the work dynamics, serving as a constant support for their team, always placing themselves in the position of responsible for solving problems and assuming their decisions; this will result in a safe team, which perceives in its leader the ability to guide, supervise and meet its demands when necessary.

Because of the characteristics of the work at the SCU, decision making was identified as an individual/professional competence of the nurse and, Therefore, specific attitudes and behaviors are necessary. When making decisions, the nurse must be assertive when analyzing the choices and be confident. In this direction, decision-making and participatory management contribute to the creation of spaces for the exchange of knowledge among workers, as well as expanding discussions, dialogue and the production of collective ideas therefore strengthening and valuing teamwork, since it allows the planning of shared care actions that stimulate commitment and accountability to the patient, as well as expanding and strengthening working relationships ${ }^{(22)}$.

It is also important to consider that when making decisions, nurses, regardless of their area of activity, are often faced with situations, which put them in front of the need to reflect before taking actions, taking into account the legal requirements for their profession, as well as social and ethical values. Because of this, ethical competence was considered essential in the formulation of the perioperative nurse work process matrix.

Lead nurses have ethical competence when they reveal the following qualities: knowing how to solve problems and identify the user's wishes, as well as that of their team; establish trust and ensure respect among the team; establish human and ethical interaction with everyone around them; empathize; be cooperative and be supportive of ones team when necessary; be fair their decisions; behave ethically towards transgressors; be honest in ones actions and have humility ${ }^{(23)}$.

The ethical competence of nurses is considered a significant factor that leads to high quality of care. However, nurses often do not feel organizational and managerial support to deal with ethical problems, therefore, it is necessary for nursing leaders to be aware of these issues and inform their team about ethical procedures and guidance practices, encouraging discussions and enabling multidisciplinary collaborations on this theme $e^{(24)}$.

From these observations, it can be considered that the identification of individual skills allows to outline/characterize the profile of a competent and qualified professional to work in SCU in different aspects related to work, making it a challenge for health organizations, as well as for training institutions, which should have as a goal and/or responsibility to outline the desired professional profile, according to the demands of the job market.

It is believed that the absence of a profile of specific individual competences for the performance of a certain function can lead to professional insecurity, lack of knowledge and/or technical skills to perform their routine tasks, as well as establishing a limited view of their potential; in addition, a competence profile that does not respond to the position can generate demotivation, overload of activities, due to the lack of knowledge to plan and manage their actions, disinterest in seeking professional improvement bringing consequences for the care provided, with the possibility of risks to the user of the service. 
On the other hand, it is emphasized that individual skills, in turn, can be developed throughout academic training or professional practice and for this reason they should not necessarily be present in the worker before being hired by SCU. In spite of this, some institutions tend to hire individuals with already developed skills, however, organizations must have a clear set of characters of the professional they want and, which give the ability, to perform a careful selection that meets the necessary requirements for recruitment of this worker. However, it is the function of the health organization to invest in the training of its employees so that new skills are constantly acquired, also contributing to the success of the organization ${ }^{(25)}$.

\section{Limitations of the Study}

This research has the limitation of having been carried out only in private institutions, not including the analysis of other professionals from other organizations of a different legal nature. Furthermore, this investigation was carried out with the exclusive participation of nurses. Therefore, it is emphasized the importance of carrying out other studies in order to cover hospital institutions of a different legal nature and of different professional categories, in order to check for divergences and/ or to determine the extent of the generalization of the findings.

\section{Contributions to the area of Nursing, Health or Public Policy}

The study allowed the construction of a matrix of individual skills for the perioperative nurse, which will allow the institution to recognize in the future regarding their human talent. Beyond that, it will be able to direct the Training Centers in the preparation of future professionals, contributing consequently to the improvement of perioperative nursing care.

\section{FINAL CONSIDERATIONS}

When meeting the objectives, it was possible to build a matrix of individual skills for nurses in SCU. For each identified competence, the nurse must have attitudes/behaviors that define them, therefore, can say that this professional has a certain competence. Providing a Matrix with this information from a professional category for a highly complex sector, such as surgical units, should assist not only the workers themselves, but the health team as a whole.

A competency matrix is also capable of directing health managers' strategies more appropriately to develop human talents in their organizations so that they respond appropriately to the corresponding positions and functions. In this sense, nursing training centers can assist the job market, responding to their demands, through transformations in their Pedagogical Projects, filling gaps in the training of future nurses, preparing them with a profile desired by health organizations and users' needs.

\section{ACKNOWLEDGMENT}

We are grateful to the Ribeirão Preto School of Nursing where it was possible to develop this research.

\section{REFERENCES}

1. Fernandes HMLG, Peniche ACG. Perception of the nursing team of a Surgical Center regarding Hospital Accreditation at a University Hospital. Rev Esc Enferm USP. 2015;49(Esp):22-28. doi: 10.1590/S0080-623420150000700004

2. Sociedade Brasileira de Enfermeiros de Centro Cirúrgico. (SOBECC) (Org.). Recuperação anestésica e centro de material e esterilização: práticas recomendadas. $7^{\circ}$ ed. São Paulo; 2017. p. 1-483.

3. Correa GC. Definição e desenvolvimento de competências: um paradigma no processo estratégico. Rev CEPE. 2015;39(67):103-116. doi: 10.17058/cepe.v0i41.6294

4. Fleury A, Fleury MTL. Estratégias empresariais e formação de competências: um quebra-cabeça caleidoscópio da indústria brasileira. $3^{a}$ ed. São Paulo: Atlas; 2004.

5. Schaupp M, Virkkunen J. Why a management concept fails to support managers' work: the case of the 'core competence of a corporation'. Manag Learn. 2017;48(1)97-109. doi: 10.1177/1350507616674632

6. Ruthes RM, Cunha ICKO. Contribuições para o conhecimento em gerenciamento de enfermagem sobre gestão por competência. Rev Gaúcha Enferm [Internet]. 2007 [cited 2019 Jul 25];28(4):570-5.5. Available from: https://seer.ufrgs.br/RevistaGauchadeEnfermagem/article/ view/3154

7. Woolf K, Page M, Viney R. Assessing professional competence: a critical review of the Annual Review of Competence Progression. J Royal Soc Med. 2019;112(6):236-244. doi: 10.1177/0141076819848113

8. Santos JLG, Lima MAD, Pestana AL, Colome ICS, Erdmann AL. Strategies used by nurses to promote teamwork in an emergency room. Rev Gaúcha Enferm. 2016;37(1):e50178. doi: 10.1590/1983-1447.2016.01.50178

9. Winsett RP, Rottet K, Schmitt A, Wathen E, Wilson D. Medical surgical nurses describe missed nursing care tasks-Evaluating our work environment. Appl Nurs Res. 2016;32:128-33. doi: 10.1016/j.apnr.2016.06.006

10. Holanda FL, Marra CC, Cunha IC. Construction of a professional competency matrix of the nurse in emergency services. Acta Paul Enferm. 2014;27(4):373-9. doi: 10.1590/1982-0194201400062

11. Soares MI, Camelo SHH, Resck ZMR. Technique of focus group in qualitative data collection: experience report. Rev Min Enferm. 2016;20:e942. doi: 10.5935/1415-2762.20160012 
12. Braun V, Clarke V. Using thematic analysis in psychology. Qual Res Psychol. 2006;3(2):77-101. doi: 10.1191/1478088706qp063oa

13. Leal LA, Soares MI, Silva BR, Bernardes A, Camelo SHH. Clinical and management skills for hospital nurses: perspective of nursing university students. Rev Bras Enferm. 2018;71(Suppl 4):1514-21. doi: 10.1590/0034-7167-2017-0452

14. Pereira LA, Hirsch CD, Silveira RS, Barlem JGT, Schalenberger CD, Barlem ELD. Nurse-leader construction process barriers: an ethnonursing. Rev Enferm UFPE. 2018;12(5):1381-9. Available from: doi: 10.5205/1981-8963-v12i5a230730p1381-1389-2018

15. Graan ACV, Williams, MJS, Koen MP. Professional nurses' understanding of clinical judgement: a contextual inquiry. Health SA Gesondheid. 2016;21(1):280-93. doi: 10.1016/j.hsag.2016.04.001

16. Silva WLAVS, Barros ATL, Santos RD, Silva LA, Miranda LN. Cirurgias cardíacas: assistência de enfermagem a portadores de cardiopatia no periodo perioperatório. Ciências Biológicas e de Saúde Unit [Internet]. 2017 [cited 2019 Jul 25];4(2):323-336. Available from: https:// periodicos.set.edu.br/index.php/fitsbiosaude/article/view/4565/2625

17. Negreiros FDS, Pequeno AMC, Garcia JHP, Aguiar MIF, Moreira TR, Flor MJN. Multi-professional team's perception of nurses' competences in liver transplantations. Rev Bras Enferm. 2017;70(2):258-64. doi: 10.1590/0034-7167-2016-0223

18. Petry K, Chesani FH, Lopes SMB. Comunicação como ferramenta de humanização hospitalar. Sal Transf Soc [Internet]. 2017 [cited 2019 Jul 25];8(2):77-85. Available from: http://incubadora.periodicos.ufsc.br/index.php/saudeetransformacao/article/view/4195

19. Camelo SHH, Rocha FLR, Chaves LDP, Silva VLS, Soares MI. Competências profissionais e estratégias organizacionais de gerentes de enfermagem. Cienc Enferm. 2016;22(1):75-86. doi: 10.4067/S0717-95532016000100007

20. Sanchez M, Vargas AV, Marinho AM, Jesus CS, Silva E, Pimenta G. A visão de enfermeiros recém-formados sobre liderança no ambiente hospitalar. Rev EDUC [Internet]. 2015 [cited 2019 Jul 25];2(2):25-36. Available from: http://uniesp.edu.br/sites/_biblioteca/ revistas/20170608151103.pdf

21. Bordin V, Almeida ML, Zilly A, Justino ET, Silva NDV, Faller JW. Liderança em enfermagem na perspectiva de enfermeiros assistenciais de um hospital público da tríplice fronteira. Rev Adm Saúde. 2018;18(71). doi: 10.23973/ras.71.107

22. Eduardo EA, Peres AM, Almeida ML, Roglio KD, Bernardino E. Analysis of the decision-making process of nurse managers: a collective reflection. Rev Bras Enferm. 2015;68(4):668-75. doi: 10.1590/0034-7167.2015680414i

23. Barkhordari SH, Ashktorab T, Atashzadeh SF. Ethical competency of nurse leaders: A qualitative study. Nurs Ethics. 2018;25(1):20-36. doi: 10.1177/0969733016652125

24. Poikkeus T, Suhonen R, Katajisto J, Leino KH. Organisational and individual support for nurses' ethical competence: a cross-sectional survey. Nurs Ethics [Internet]. 2018 [cited 2019 Jul 25];25(3):376-92. doi: 10.1177/0969733016642627

25. Mello AL, Brito LJS, Terra MG, Camelo SH. Organizational strategy for the development of nurses' competences: possibilities of Continuing Education in Health. Esc Anna Nery. 2018;22(1):e20170192. doi: 10.1590/2177-9465-ean-2017-0192 